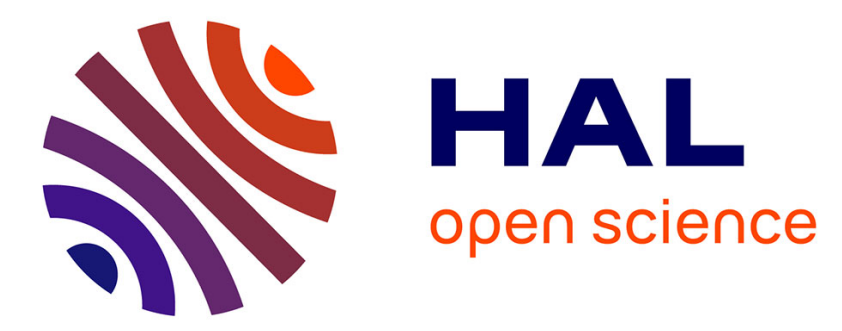

\title{
Hydroxyapatite starting from calcium carbonate and orthophosphoric acid: synthesis, characterization, and applications
}

Doan Pham Minh, Sébastien Rio, Patrick Sharrock, Haroun Sebei, Nathalie Lyczko, Ngoc Dung Tran, Mohamed Raii, Ange Nzihou

\section{To cite this version:}

Doan Pham Minh, Sébastien Rio, Patrick Sharrock, Haroun Sebei, Nathalie Lyczko, et al.. Hydroxyapatite starting from calcium carbonate and orthophosphoric acid: synthesis, characterization, and applications. Journal of Materials Science, 2014, 49 (12), p.4261-4269. 10.1007/s10853-014-8121-7 . hal-01625023

\section{HAL Id: hal-01625023 \\ https://hal.science/hal-01625023}

Submitted on 20 Oct 2018

HAL is a multi-disciplinary open access archive for the deposit and dissemination of scientific research documents, whether they are published or not. The documents may come from teaching and research institutions in France or abroad, or from public or private research centers.
L'archive ouverte pluridisciplinaire HAL, est destinée au dépôt et à la diffusion de documents scientifiques de niveau recherche, publiés ou non, émanant des établissements d'enseignement et de recherche français ou étrangers, des laboratoires publics ou privés. 


\title{
Hydroxyapatite starting from calcium carbonate and orthophosphoric acid: synthesis, characterization, and applications
}

\author{
Doan Pham Minh - Sébastien Rio - Patrick Sharrock • \\ Haroun Sebei • Nathalie Lyczko • Ngoc Dung Tran • \\ Mohamed Raii · Ange Nzihou
}

\begin{abstract}
Hydroxyapatite $\left[\mathrm{Ca}_{10}\left(\mathrm{PO}_{4}\right)_{6}(\mathrm{OH})_{2}\right]$, Ca-HA, is the emblematic mineral phase of bones, and is known for its complexity and difficult to reproduce chemical synthesis. Among the routes developed for obtaining this calcium phosphate, the so-called double-decomposition method is well described and often utilized. However, the Ca-HA synthesized by this way forms a larger mass of ammonium nitrate by-product than the desired product itself. Pure CaHA for orthopedic or dental applications usually uses thermal treatment to eliminate residual nitrogen compounds by releasing them in the atmosphere. Contemporary sol-gel methods currently in fashion produce even more degradation products including solvents and precursor organics. We now report on a green synthesis procedure which makes pure Ca-HA with minimum by-product. The
\end{abstract}

D. Pham Minh $(\bowtie) \cdot$ S. Rio · P. Sharrock · H. Sebei ·

N. Lyczko · N. D. Tran · M. Raii · A. Nzihou

Université de Toulouse, Mines Albi, UMR CNRS 5302, Centre

RAPSODEE, Campus Jarlard, 81013 Albi Cedex 09, France

e-mail: doan.phamminh@mines-albi.fr

S. Rio

e-mail: sebastien.rio@mines-albi.fr

P. Sharrock

e-mail: patrick.sharrock@iut-tlse3.fr

H. Sebei

e-mail: hsebei@hotmail.fr

N. Lyczko

e-mail: lyczko@mines-albi.fr

N. D. Tran

e-mail: ngoc-dung.tran@mines-albi.fr

M. Raii

e-mail: mohamed.raii@yahoo.fr

\section{A. Nzihou}

e-mail: ange.nzihou@mines-albi.fr synthesis calls for reacting phosphoric acid with calcium carbonate in water suspension to form a Ca-HA gel of fine particles. This gel can be filtered and the solids recovered, dried, and sintered, but can also be used as-is for environmental applications such as heavy metal ions or textile dye removal from polluted waste streams. This green $\mathrm{Ca}-$ HA has been used to trap heavy metals in flue gases and in municipal waste water treatment plants. This low-cost and low-environmental impact material can be developed for medical use because of its absence of impurities, and in catalytic productions for remediation of many environmental problems. Recent results show Ca-HA can also serve in reforming biogas compositions into useful products, after deposition of selected metal elements. Some of these results will be communicated in this paper.

\section{Introduction}

Hydroxyapatite $\left[\mathrm{Ca}_{10}\left(\mathrm{PO}_{4}\right)_{6}(\mathrm{OH})_{2}\right]$, labeled thereafter Ca$\mathrm{HA}$, is well known as a multi-function/multi-utilization material in different fields including biomaterials and food industry [1-4]. As the main component of animal bone and defects, Ca-HA-based materials are largely used for reconstruction or replacement of human bone defects [2, 5]. Ca-HA is also widely used as nutrient supplements in drinks, meats, or animal foods [4]. During the last years, research has been strongly focused on the use of $\mathrm{Ca}-\mathrm{HA}$ in the fields of heterogeneous catalysis and toxic metal fixation. Catalytic use of Ca-HA relates to its intrinsic acidbasic properties, possible high-specific surface area, thermal stability, and capacity to support different active phases including metals, metal salts, and oxides etc. [610]. The performance of $\mathrm{Ca}-\mathrm{HA}$ for the removal of toxic metal from an aqueous solution has been also widely 
demonstrated at laboratory scale. Ca-HA has strong affinity for the fixation of different metals including lead, cadmium, copper, zinc, strontium, mercury, cobalt, etc. [1116]. However, to the best of our knowledge, there is no application of Ca-HA at industrial scale for the treatment of wastewaters, despite a large number of laboratory reports with very promising results. In fact, for the viability of a given process, in particular for environmental purposes, costs must be minimized.

Various processes have been developed for the synthesis of Ca-HA. We now review the principal methods for $\mathrm{Ca}$ HA synthesis, prior to communicating our synthesis strategy for obtaining Ca-HA from low-cost starting materials.

Double decomposition is the most common method for the synthesis of Ca-HA. It consists in the decomposition of both calcium and phosphate sources, for example $\mathrm{Ca}\left(\mathrm{NO}_{3}\right)_{2}$ and $\left(\mathrm{NH}_{4}\right)_{2} \mathrm{HPO}_{4}$ [18] or $\mathrm{NH}_{4} \mathrm{H}_{2} \mathrm{PO}_{4}$ [7], in an aqueous solution to form $\mathrm{Ca}-\mathrm{HA}$ precipitate. Ammonium hydroxide is usually used for the control of $\mathrm{pH}$. At room temperature, the reaction time was found to be crucial for the formation of a pure apatitic phase, as described previously $[19,20]$. Ca-HA of high-specific surface area (up to about $150 \mathrm{~m}^{2} \mathrm{~g}^{-1}$ ) was obtained [7]. But the product needs to be filtered and washed several times to eliminate all counter-ions, i.e., $\mathrm{NO}_{3}{ }^{-}$and $\mathrm{NH}_{4}{ }^{+}$[18]. This step is usually arduous since fine $\mathrm{Ca}-\mathrm{HA}$ particles are formed by precipitation. Considering the theoretical equation for the formation of $\mathrm{Ca}-\mathrm{HA}$ from $\mathrm{Ca}\left(\mathrm{NO}_{3}\right)_{2}$ and $\mathrm{NH}_{4} \mathrm{H}_{2} \mathrm{PO}_{4}$ [8], $\left(\mathrm{NH}_{4}\right)_{2} \mathrm{HPO}_{4}$ [18], or $\left(\mathrm{NH}_{4}\right)_{3} \mathrm{PO}_{4}$ [19], the quantity of byproducts generated by this way is higher than the mass of Ca-HA (Eqs. 1-3). The difficulty of filtering and washing steps, the generation of by-products, and the high costs of the starting materials are the main drawbacks of this process.

$$
\begin{aligned}
& 10 \mathrm{Ca}\left(\mathrm{NO}_{3}\right)_{2}+6 \mathrm{NH}_{4} \mathrm{H}_{2} \mathrm{PO}_{4}+14 \mathrm{NH}_{4} \mathrm{OH} \\
& \rightarrow \mathrm{Ca}_{10}\left(\mathrm{PO}_{4}\right)_{6}(\mathrm{OH})_{2}+20 \mathrm{NH}_{4} \mathrm{NO}_{3}+12 \mathrm{H}_{2} \mathrm{O} \\
& 10 \mathrm{Ca}\left(\mathrm{NO}_{3}\right)_{2}+6\left(\mathrm{NH}_{4}\right)_{2} \mathrm{HPO}_{4}+8 \mathrm{NH}_{4} \mathrm{OH} \\
& \rightarrow \mathrm{Ca}_{10}\left(\mathrm{PO}_{4}\right)_{6}(\mathrm{OH})_{2}+20 \mathrm{NH}_{4} \mathrm{NO}_{3}+6 \mathrm{H}_{2} \mathrm{O} \\
& 10 \mathrm{Ca}\left(\mathrm{NO}_{3}\right)_{2}+6\left(\mathrm{NH}_{4}\right)_{3} \mathrm{PO}_{4}+2 \mathrm{NH}_{4} \mathrm{OH} \\
& \rightarrow \mathrm{Ca}_{10}\left(\mathrm{PO}_{4}\right)_{6}(\mathrm{OH})_{2}+20 \mathrm{NH}_{4} \mathrm{NO}_{3}
\end{aligned}
$$

Sol-gel technique is also commonly used for the synthesis of a large number of solid materials, including $\mathrm{Ca}$ HA [21-24]. Bezzi et al. [21], Anee et al. [22], and Bakan et al. [24] detailed the synthesis of Ca-HA by this method starting from $\mathrm{Ca}\left(\mathrm{NO}_{3}\right)_{2},\left(\mathrm{NH}_{4}\right)_{2} \mathrm{HPO}_{4}$, and $\mathrm{NH}_{4} \mathrm{H}_{2} \mathrm{PO}_{4}$ as starting reactants. Ammonium donor agents such as urea and ammonium hydroxide, gelling agents such as ethylenediamminetetraacetic acid (EDTA), and organic solvent such as ethanol were also used in this method. However, this approach calls for a multi-step synthesis, as illustrated in the flow sheet by Bezzi et al. [21], with the generation of a very large quantity of by-products. For example, the production of $100 \mathrm{~g}$ of $\mathrm{Ca}-\mathrm{HA}$ required $260 \mathrm{~g}$ of $\mathrm{Ca}\left(\mathrm{NO}_{3}\right)_{2} \cdot 4 \mathrm{H}_{2} \mathrm{O}, 80 \mathrm{~g}$ of $\left(\mathrm{NH}_{4}\right)_{2} \mathrm{HPO}_{4}, 360 \mathrm{~g}$ of EDTA, and $90 \mathrm{~g}$ of urea [21]. This does not conform to the actual tendency of green chemistry.

Ca-HA nanoparticles with controlled morphologies could be obtained by reverse microemulsion technique using $\mathrm{Ca}\left(\mathrm{NO}_{3}\right)_{2}$ and $\mathrm{H}_{3} \mathrm{PO}_{4}$ as starting materials and different organic solvents and surfactants [25]. These last ones are water-immiscible and form a reverse micelle with the aqueous phase. Ca-HA with different morphologies and specific surface areas could be obtained under the effect of various parameters such as ratios of inorganic cation to anion, ratios of water to oil, the nature of surfactant, etc. However, this procedure is not environmentally friendly because all organic solvents and surfactants were evaporated and burned for the recovery of Ca-HA powder. Gopi et al. [26] investigated the Ca-HA nanoparticles in an aqueous solution using glycine-acrylic acid as templates. Ca-HA particles of about one hundred $\mathrm{nm}$ were formed but a large amount of templates was required $(20 \mathrm{~mol}$ of templates for $5 \mathrm{~mol}$ of $\mathrm{Ca}\left(\mathrm{NO}_{3}\right)_{2} \cdot 4 \mathrm{H}_{2} \mathrm{O}$ and $3 \mathrm{~mol}$ of $\left.\left(\mathrm{NH}_{4}\right)_{2} \mathrm{HPO}_{4}\right)$ and which were also found as by-products of the synthesis process after filtration and washing steps.

Mechanochemical route via solid-solid reaction was also described for the synthesis of Ca-HA particles [27, 28]. It consists in the milling of a solid mixture of calcium and phosphate sources. This technique can prevent the use of a solvent. However, the reaction may be incomplete despite long reaction times under rigorous conditions (high-rotation rate, high-weight ratio of milling balls to solid reactants) [27].

In order to reduce or eliminate the generation of byproducts, a synthesis process using calcium hydroxide and orthophosphoric acid as starting materials was developed $[7,29,30]$. In general, calcium hydroxide suspension could be progressively neutralized by orthophosphoric acid. In fact, these two reactants contain only $\mathrm{H}^{+}$and $\mathrm{OH}^{-}$as counter-ions leading to the absence of any by-product other than water (Eq. 4). So, no further purification step is required for this process. Ca-HA of food and pharmaceutical grade is actually produced by this way at the industrial scale $[4,29]$.

$10 \mathrm{Ca}(\mathrm{OH})_{2}+6 \mathrm{H}_{3} \mathrm{PO}_{4} \rightarrow \mathrm{Ca}_{10}\left(\mathrm{PO}_{4}\right)_{6}(\mathrm{OH})_{2}+8 \mathrm{H}_{2} \mathrm{O}$

According to Eq. (4), the use of $\mathrm{Ca}(\mathrm{OH})_{2}$ and $\mathrm{H}_{3} \mathrm{PO}_{4}$ should generate $\mathrm{Ca}-\mathrm{HA}$ and avoid the generation of byproducts. But the energetic and economic balance of the process can still be improved. Indeed, $\mathrm{Ca}(\mathrm{OH})_{2}$ is obtained 
by calcination followed by hydration of $\mathrm{CaCO}_{3}$. This last one is abundantly available in nature as the cheapest calcium source. From this point of view, we focused our latest research on the use of $\mathrm{CaCO}_{3}$ and $\mathrm{H}_{3} \mathrm{PO}_{4}$ as starting reactants for the synthesis of Ca-HA under moderate conditions. The only by-product of the reaction is carbonic gas, which automatically leaves the reaction mixture. The expected reaction is written as follows:

$$
\begin{aligned}
10 \mathrm{CaCO}_{3}+6 \mathrm{H}_{3} \mathrm{PO}_{4} \rightarrow & \mathrm{Ca}_{10}\left(\mathrm{PO}_{4}\right)_{6}(\mathrm{OH})_{2}+10 \mathrm{CO}_{2} \\
& +8 \mathrm{H}_{2} \mathrm{O}
\end{aligned}
$$

In this paper, we present the one-step synthesis of Ca$\mathrm{HA}$ from $\mathrm{CaCO}_{3}$ and $\mathrm{H}_{3} \mathrm{PO}_{4}$. The reactivity of the resulting Ca-HA in different applications is also described, in particular for the treatment of synthetic and real wastewaters containing toxic metals and organic pollutants.

\section{Materials and methods}

Chemical products

Calcium carbonate powder (98\%, Fisher Scientific) and orthophosphoric acid ( $85 \mathrm{wt} \%$ in water, Merck) were used as received. All other chemical products such as lead(II) nitrate, lead(II) chloride, etc. were also purchased from commercial suppliers including Fisher Scientific, Merck, Labosi, and Prolabo.

Synthesis of Ca-HA at atmospheric pressure

This synthesis was carried out in an open glass U-form reactor (i.d.: $10 \mathrm{~cm}$, length: $30 \mathrm{~cm}$, volume: $2.3 \mathrm{~L}$ ) with a vertical stainless-steel stirrer. For a given synthesis, $800 \mathrm{~mL}$ of water and $200 \mathrm{~g}$ of $\mathrm{CaCO}_{3}(2 \mathrm{~mol})$ were introduced in the reactor under stirring (400 rpm). When the $\mathrm{pH}$ of the suspension was stable, $80 \mathrm{~mL}$ of $\mathrm{H}_{3} \mathrm{PO}_{4}(1.2 \mathrm{~mol})$ was pumped into the suspension of $\mathrm{CaCO}_{3}$ at the rate of $2 \mathrm{~mL} \mathrm{~min}^{-1}$. The reaction was kept at constant temperature $\left(80{ }^{\circ} \mathrm{C}\right)$ for different reaction times. Aliquots withdrawn from the reaction mixture were filtered on a $0.45 \mu \mathrm{m}$ filter paper to separate liquid and solid phases at different reaction times. The solid was washed and dried overnight prior to further analyses and characterizations. The liquid phase was acidified with nitric acid to avoid any further precipitation from calcium cations and orthophosphate species present in the liquid phase.

Physico-chemical characterizations

X-ray diffraction (XRD) of powder products was carried out on a Phillips Panalytical X'pert Pro MPD diffractometer.
Simultaneous thermogravimetry and differential scanning calorimetry (TG-DSC) analysis was carried out in a TA Instruments SDTQ600 analyzer with a heating rate of $5{ }^{\circ} \mathrm{C} \min ^{-1}$.

Scanning electron microscopy coupled with energydispersive X-ray spectroscopy (SEM-EDX) measurement was performed on a Philips XL30 ESEM apparatus.

Infra-red (IR) spectroscopy measurement was carried out on a Shimadzu FTIR 8400S spectrometer.

The rheological behavior of Ca-HA gel was investigated using a 135 Rheostress (HAAKE RS 150 rheometer). Dynamic viscosity was measured in the shear rate range of $0-500 \mathrm{~s}^{-1}$ at $20{ }^{\circ} \mathrm{C}$.

The elemental analysis of phosphorus and calcium in the liquid phase was carried out with inductively coupled plasma atomic emission spectroscopy (ICP-AES) on a HORIBA Jobin-Yvon Ultima 2.

\section{Results}

Ca-HA synthesis

The initial suspension of $\mathrm{CaCO}_{3}$ had a basic $\mathrm{pH}$ of 8.8 at $80{ }^{\circ} \mathrm{C}$. When the first drops of $\mathrm{H}_{3} \mathrm{PO}_{4}$ were added, carbonic gas was strongly emitted from the reaction mixture. The $\mathrm{pH}$ of the suspension decreased rapidly to about 4 . Then, it increased slowly to about 6.5 after $24 \mathrm{~h}$ of reaction at $80{ }^{\circ} \mathrm{C}$. After cooling to room temperature, a stable gel containing fine particles (SEM analysis section) was obtained. This gel contained about $70 \mathrm{wt} \%$ of water, determined by weight loss measurement at $105{ }^{\circ} \mathrm{C}$. As shown in Fig. 1, the dynamic viscosity of the gel decreased with the increase of shear rate, signifying that this gel behaved as a thixotropic fluid. The critical value of the dynamic viscosity $\left(\eta_{\infty}\right)$ reached $0.14 \mathrm{~Pa}$ s when the shear

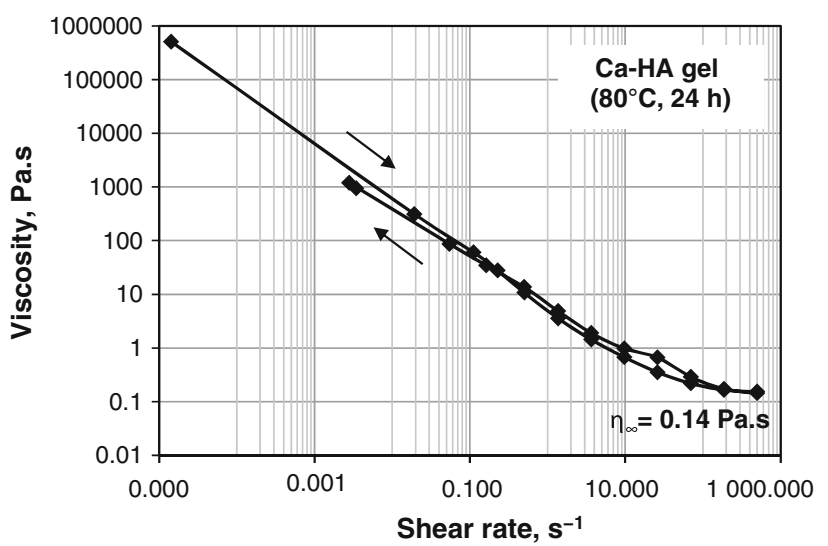

Fig. 1 Dynamic viscosity against shear rate for the Ca-HA gel synthesized at $80{ }^{\circ} \mathrm{C}$ for $24 \mathrm{~h}$ 
rate was at $500 \mathrm{~s}^{-1}$. Above this point, the liquid flowed. When the shear stress was stopped, the liquid recovered its structure.

Elemental analysis of the filtrate (liquid phase) by ICPAES shows that soluble calcium and phosphate species were present at very low concentration, which were all smaller than $1 \mathrm{mmol} \mathrm{L}^{-1}$. This means that all initial calcium and phosphate were transformed and/or remained in the solid state. The analysis of the solids obtained at 3 and $24 \mathrm{~h}$ of reaction shows also that the molar ratio of $\mathrm{Ca}$ to $\mathrm{P}$ was close to 1.67 , which was the initial value of the reactant mixture introduced into the reactor.

TG analyses of the solid samples withdrawn at different reaction times from the reactor are present in Fig. 2. The first weight loss below $100{ }^{\circ} \mathrm{C}$ corresponded to the evaporation of surface moisture which was similar for both solids obtained at 3 and $24 \mathrm{~h}$ of reaction. The next weight loss at $112{ }^{\circ} \mathrm{C}$ could be attributed to the dehydration of monocalcium phosphate monohydrate (MCPM, $\mathrm{Ca}\left(\mathrm{H}_{2-}\right.$ $\left.\mathrm{PO}_{4}\right)_{2} \cdot 2 \mathrm{H}_{2} \mathrm{O}$ ) [31]. The slight next weight losses in the temperature range of $175-360{ }^{\circ} \mathrm{C}$ may be attributed to the dehydration/condensation of DCPD (dicalcium phosphate dehydrate, or brushite, $\mathrm{CaHPO}_{4} \cdot 2 \mathrm{H}_{2} \mathrm{O}$ ) and DCPA (dicalcium phosphate anhydride, or monetite, $\mathrm{CaHPO}_{4}$ ) [31]. Residual calcium carbonate was thermally decomposed around $610{ }^{\circ} \mathrm{C}$, followed by the decarbonation of carbonated apatite (CAP) around $720{ }^{\circ} \mathrm{C}[31,32]$. In parallel with these apparent weight losses, a continuous weight loss was observed with the increase of the temperature up to $1310^{\circ} \mathrm{C}$, which was assigned to the partial transformation of $\mathrm{OH}^{-}$anions of Ca-HA to molecular water and bivalent oxygen. This transformation was nearly completed when the temperature reached $1310{ }^{\circ} \mathrm{C}$ and oxyapatite (OAP, $\left.\mathrm{Ca}_{10}\left(\mathrm{PO}_{4}\right)_{6} \mathrm{O}\right)$ was formed [33]. All these weight losses were endothermic (DSC results not presented).

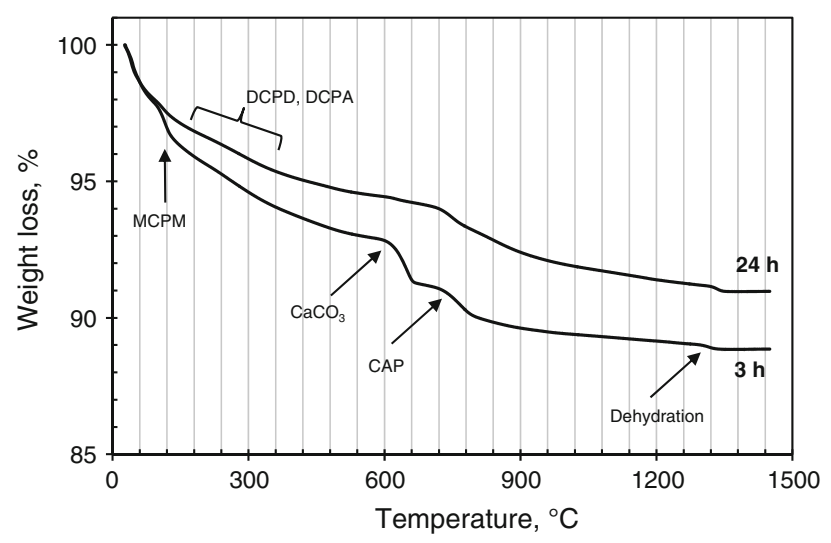

Fig. 2 TG curves of the solid samples withdrawn from the reactor at different reaction times
From TG curves, the content of residual calcium carbonate could be calculated, which was 4.0 and $0.6 \mathrm{wt} \%$ for the solids withdrawn at 3 and $24 \mathrm{~h}$ of reaction, respectively. So, the reaction at $80^{\circ} \mathrm{C}$ for $24 \mathrm{~h}$ allowed converting nearly completely the initial calcium carbonate into calcium phosphates. This temperature of $80^{\circ} \mathrm{C}$ was found as the critical value, because below $80^{\circ} \mathrm{C}$ high-residual quantities of calcium carbonate remained in solid products despite a long reaction time of $72 \mathrm{~h}$ (results not presented).

In order to identify the crystalline phase of the resulting solid calcium phosphates, XRD was performed, and Fig. 3 presents XRD patterns of the solids obtained at 3 and $24 \mathrm{~h}$ of reaction.

As expected, only small amounts of calcium carbonate $\left(2 \theta\right.$ of $29.400^{\circ}$ ) remained in the solid product obtained after $3 \mathrm{~h}$ of reaction, and trace quantities were found in the solid product obtained after $24 \mathrm{~h}$ of reaction. This confirmed again the results of TG analyses above for the content of residual calcium carbonate. All other peaks corresponded to the pattern of Ca-HA, as the main crystalline calcium phosphate formed. Some traces of CAP were also detected as observed by TG analysis.

In summary, the one-step reaction of calcium carbonate powder with orthophosphoric acid in an aqueous solution (weight ratio of water to calcium carbonate equal to 4 , and molar ratio of calcium to phosphorus equal to 1.67) at $80{ }^{\circ} \mathrm{C}$ for $24 \mathrm{~h}$ led to (i) a nearly-complete decomposition of calcium carbonate; (ii) the formation of $\mathrm{Ca}-\mathrm{HA}$ as the main crystalline phase of the solid product; (iii) the formation of a stable gel containing fine Ca-HA particles; and (iv) the absence of soluble counter-ions in the Ca-HA gel. The advantages of the present synthesis process compared

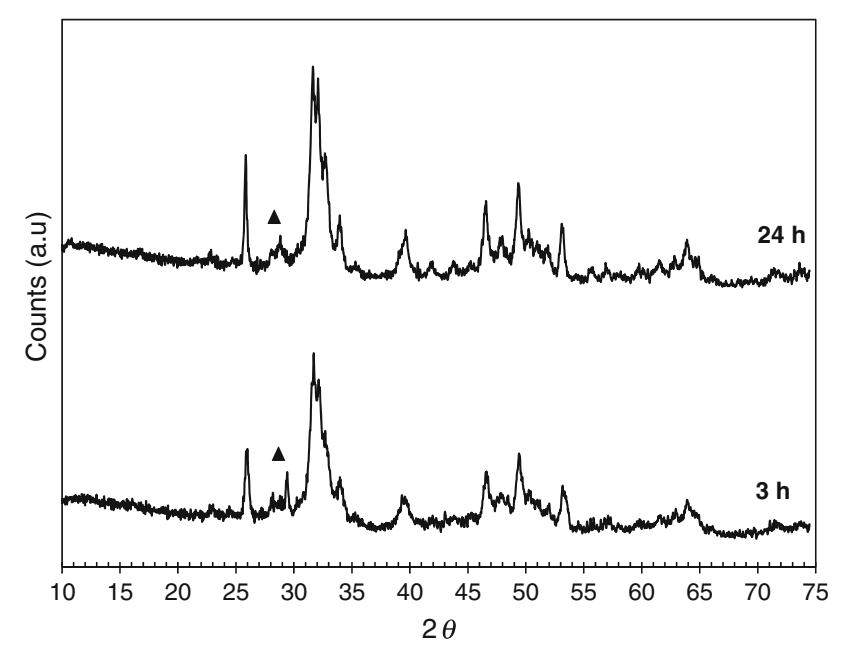

Fig. 3 XRD patterns of the solid products synthesized at $80{ }^{\circ} \mathrm{C}$ for 3 and $24 \mathrm{~h}$; filled triangle calcite (JCPDS standard no. 00-047-1743); other peaks Ca-HA (JCPDS standard no. 01-072-1243) 
Table 1 Summary of different processes for the synthesis of Ca-HA

\begin{tabular}{|c|c|c|c|c|c|c|}
\hline $\begin{array}{l}\text { Calcium } \\
\text { source }\end{array}$ & $\begin{array}{l}\text { Phosphate } \\
\text { source }\end{array}$ & $\begin{array}{l}\text { Surfactant, } \\
\text { template }\end{array}$ & $\begin{array}{l}\text { Synthesis } \\
\text { conditions }\end{array}$ & Main advantages & Main drawbacks & Ref \\
\hline $\mathrm{CaCO}_{3}$ & $\mathrm{H}_{3} \mathrm{PO}_{4}$ & No & $80{ }^{\circ} \mathrm{C}, 24 \mathrm{~h}$ & $\begin{array}{l}\text { One-step synthesis } \\
\text { Low-cost reactants } \\
\text { Moderate } \\
\text { conditions }\end{array}$ & Only $\mathrm{CO}_{2}$ as by-product & $\begin{array}{l}\text { This } \\
\text { work }\end{array}$ \\
\hline $\mathrm{Ca}(\mathrm{OH})_{2}$ & $\mathrm{H}_{3} \mathrm{PO}_{4}$ & No & $\begin{array}{l}80-90{ }^{\circ} \mathrm{C}, \\
24 \mathrm{~h}\end{array}$ & $\begin{array}{l}\text { One-step synthesis } \\
\text { Without residues } \\
\text { Moderate } \\
\text { conditions }\end{array}$ & Calcination of $\mathrm{CaCO}_{3}$ into $\mathrm{Ca}(\mathrm{OH})_{2}$ & [8] \\
\hline $\mathrm{Ca}\left(\mathrm{NO}_{3}\right)_{2}$ & $\begin{array}{l}\mathrm{NH}_{4} \mathrm{H}_{2} \mathrm{PO}_{4} \\
\left(\mathrm{NH}_{4}\right)_{2} \mathrm{HPO}_{4} \\
\left(\mathrm{NH}_{4}\right)_{3} \mathrm{PO}_{4}\end{array}$ & No & $\begin{array}{l}25-80{ }^{\circ} \mathrm{C} \\
\text { up to } \\
120 \mathrm{~h}\end{array}$ & $\begin{array}{l}\text { Good homogeneity } \\
\text { of the reaction } \\
\text { mixture }\end{array}$ & $\begin{array}{l}\text { Great quantity of by-products in both } \\
\text { liquid and gas phases High cost of the } \\
\text { initial reactants }\end{array}$ & $\begin{array}{c}{[8,18,} \\
19]\end{array}$ \\
\hline $\mathrm{CaCl}_{2}$ & $\mathrm{Na}_{3} \mathrm{PO}_{4}$ & No & $\begin{array}{l}\text { Microwave } \\
\text { assisted } \\
\text { synthesis }\end{array}$ & $\begin{array}{l}\text { Good homogeneity } \\
\text { of the reaction } \\
\text { mixture }\end{array}$ & $\begin{array}{l}\mathrm{Na}^{+} \text {and } \mathrm{Cl}^{-} \text {as by-products High cost of } \\
\text { the initial reactants }\end{array}$ & [34] \\
\hline $\mathrm{CaCl}_{2}$ & $\left(\mathrm{NH}_{4}\right)_{2} \mathrm{HPO}_{4}$ & $\begin{array}{l}\text { Petroleum ether } \\
\text { as oil phase, } \\
\text { KB6ZA as } \\
\text { surfactant }\end{array}$ & Sol-gel & $\begin{array}{l}\text { Good homogeneity } \\
\text { of the reaction } \\
\text { mixture }\end{array}$ & $\begin{array}{l}\text { Great quantity of by-products (inorganic } \\
\text { and organic) in both liquid and gas } \\
\text { phases High cost of the initial reactants }\end{array}$ & [35] \\
\hline $\mathrm{Ca}\left(\mathrm{NO}_{3}\right)_{2}$ & $\begin{array}{l}\mathrm{H}_{3} \mathrm{PO}_{4} \\
\quad\left(\mathrm{NH}_{4}\right)_{2} \mathrm{HPO}_{4}\end{array}$ & $\begin{array}{l}\text { Glycine, acrylic, } \\
\text { C6, C12, C } 20, \\
\text { polymers }\end{array}$ & Sol-gel & $\begin{array}{l}\text { Good homogeneity } \\
\text { of the reaction } \\
\text { mixture }\end{array}$ & $\begin{array}{l}\text { Great quantity of by-products (inorganic } \\
\text { and organic) in both liquid and gas } \\
\text { phases High cost of the initial reactants }\end{array}$ & $\begin{array}{l}{[25,} \\
26]\end{array}$ \\
\hline$\left(\mathrm{Ca}\left(\mathrm{C}_{2} \mathrm{H}_{3} \mathrm{O}_{2}\right)_{2}\right.$ & $\left(\mathrm{PO}\left(\mathrm{OC}_{2} \mathrm{H}_{5}\right)_{3}\right.$ & Alcohols & Sol-gel & $\begin{array}{l}\text { Good homogeneity } \\
\text { of the reaction } \\
\text { mixture }\end{array}$ & $\begin{array}{l}\text { Multi-step, great quantity of by-products, } \\
\text { calcinations at } 100{ }^{\circ} \mathrm{C} \text { High cost of the } \\
\text { initial reactants }\end{array}$ & [36] \\
\hline
\end{tabular}

to the literature data are given in Table 1 . No residue generated the use of $\mathrm{Ca}(\mathrm{OH})_{2}$ and $\mathrm{H}_{3} \mathrm{PO}_{4}$ as starting reactants. However, $\mathrm{Ca}(\mathrm{OH})_{2}$ costs more than $\mathrm{CaCO}_{3}$, since $\mathrm{Ca}(\mathrm{OH})_{2}$ is industrially obtained from $\mathrm{CaCO}_{3}$ by calcination and hydration steps. We will see in the next section that the additional benefit in the use of $\mathrm{CaCO}_{3}$ compared to $\mathrm{Ca}(\mathrm{OH})_{2}$, when synthesized $\mathrm{Ca}-\mathrm{HA}$ is used for the fixation of toxic metals. Compared to other soluble calcium and orthophosphate sources, the present process has as advantages to be in one-step at moderate conditions; to generate $\mathrm{CO}_{2}$ as the only by-product; and to use the cheapest initial reactants.

Reactivity of the as-synthesized Ca-HA in the removal of lead(II) from an aqueous solution

We were successful in the preparation of Ca-HA from $\mathrm{CaCO}_{3}$ and $\mathrm{H}_{3} \mathrm{PO}_{4}$ by a one-step synthesis process. Two types of products were obtained: (i) $\mathrm{Ca}-\mathrm{HA}$ gel which was the as-synthesized product; and (ii) $\mathrm{Ca}-\mathrm{HA}$ powder which was obtained from Ca-HA gel after classical filtering and drying steps. It is interesting now to test their reactivity/ property in some selected applications.

Ca-HA gel and powder (filtered and dried overnight at $105{ }^{\circ} \mathrm{C}$ ) were first tested in the removal of lead(II) as a model toxic metal. An aqueous solution containing $6000 \mathrm{mg} \mathrm{L}^{-1}$ of $\mathrm{Pb}^{2+}$ ions was prepared from lead nitrate and distilled water. This concentration was chosen for the evaluation of sorption capacity of the sorbents. For the lead(II) removal experiment, $300 \mathrm{~mL}$ of the prepared lead nitrate solution was introduced into a $700 \mathrm{~mL}$ glass reactor. Then $2.4 \mathrm{~g}$ of $\mathrm{Ca}-\mathrm{HA}$ powder or an equivalent quantity of Ca-HA gel was added into the reactor at the stirring speed of $350 \mathrm{rpm}$ and at ambient temperature, ca. $25^{\circ} \mathrm{C}$. The concentrations of lead, calcium, and phosphorus in solution during the run were determined using the ICP-AES technique.

Figure 4 shows the abatement of lead(II) when Ca-HA gel and Ca-HA powder were used in the same experimental conditions. Ca-HA gel shows faster lead(II) removal kinetics compared to that of Ca-HA powder. For example, at $180 \mathrm{~min}$ of contact, the removal of lead(II) reached 73 and $36 \%$ for Ca-HA gel and Ca-HA powder, respectively. The filtration and drying steps may reduce partially the lability of the active species on the surface of Ca-HA particles [37, 38]. For both sorbents, lead(II) was nearly totally removed from the solution, at different contact times. This means that the sorption capacity $\left(Q_{\mathrm{e}}\right)$ of these two sorbents can reach at least $750 \mathrm{mg}_{\mathrm{Pb}} \mathrm{g}_{\text {sorbent }}^{-1}$. This $Q_{\mathrm{e}}$ is much higher than those found in the literature for the sorption of lead(II) by Ca-HA synthesized from soluble calcium salt such as calcium nitrate, which did not exceed $450 \mathrm{mg}_{\mathrm{Pb}} \mathrm{g}_{\text {sorbent }}^{-1}$ [11]. This higher performance of Ca-HA synthesized from $\mathrm{CaCO}_{3}$ as calcium source can be related 


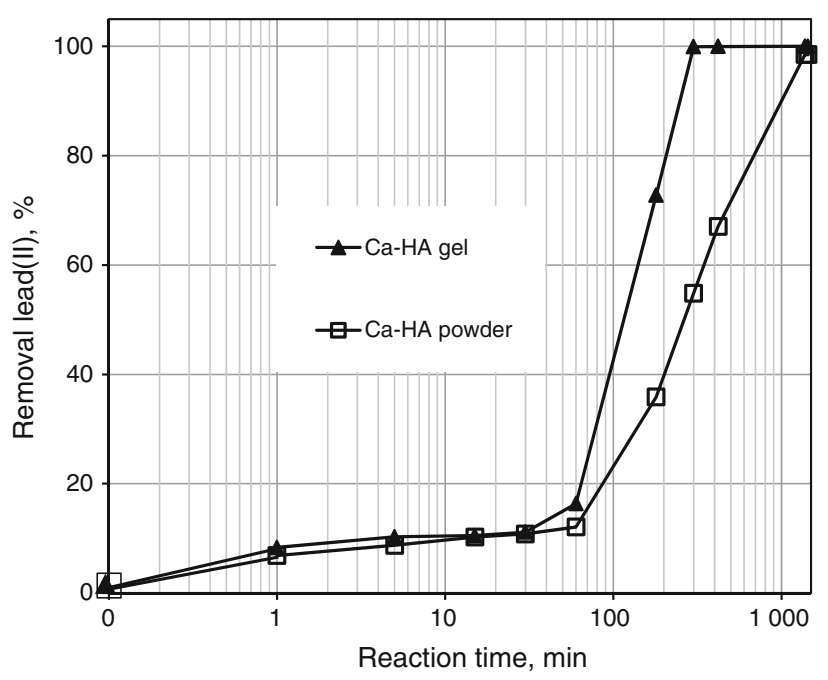

Fig. 4 Removal of lead(II) as a function of contact time using Ca-HA gel and $\mathrm{Ca}-\mathrm{HA}$ powder as sorbents

to the insertion of carbonate anions in the apatitic structure, as shown previously by Miyake et al. [39]. The replacement of a phosphate anion by a carbonate anion leads to a destabilization of the apatitic structure because of the change in charge balance. Carbonate anions can be attacked by the acidity of lead nitrate solution (initial $\mathrm{pH}$ of about 5). This promotes the fixation of lead(II) on Ca-HA particles. XRD analysis of the solid recovered after lead(II) removal showed the formation of lead hydroxyapatite $\left(\mathrm{Pb}_{10}\left(\mathrm{PO}_{4}\right)_{6}(\mathrm{OH})_{2}\right.$, JCPDS standard No. 01-087-2477) as the main lead-containing crystalline phase (results not presented). SEM observation highlighted also the fixation of lead on the surface of Ca-HA particles (Fig. 5). Ca-HA powder dried at $105^{\circ} \mathrm{C}$ contained micrometric particles of various sizes (Fig. 5a). Layers of lead-containing compounds were observed on the surface of the solid recovered after lead(II) removal experiment (Fig. 5b). No evidence of lead(II) migration inside the solid particles was observed, when SEM images were focused on polished sections of particles, initially immobilized in a resin matrix (Fig. 5c). The presence of lead occurred only inside porous particles, with lead coating the inner surfaces of the pores. There was no evidence for the formation of a mixed calcium and lead phosphate or solid solution of lead and calcium phosphate.

Reactivity of the as-synthesized Ca-HA in the removal of lead(II) from a flue gas

Work has been done on the fixation of several toxic metals in aqueous solutions on $\mathrm{Ca}-\mathrm{HA}$ powder. However, there is practically no study on the fixation of metals in gas phase using Ca-HA-based materials. This part communicates first results on the fixation of lead(II) from a flue gas onto $\mathrm{Ca}$ HA powder.
A $5 \mathrm{wt} \% \mathrm{PbCl}_{2} / \mathrm{CaCO}_{3}$ was prepared from commercial $\mathrm{PbCl}_{2}$ and $\mathrm{CaCO}_{3}$ powder by impregnation, which was then used as the source of vaporized lead(II) by heating at $600-850{ }^{\circ} \mathrm{C}$. Detailed kinetic study on the vaporization of $\mathrm{PbCl}_{2}$-supported $\mathrm{CaCO}_{3}$ was shown previously [40]. The abatement of vaporized lead(II) was carried out in a horizontal tubular quartz tube which was heated electrically at 600-850 ${ }^{\circ} \mathrm{C}$ (Fig. 6). When the reactor reached the desired temperature, a weighed quantity of $5 \mathrm{wt} \% \mathrm{PbCl}_{2} / \mathrm{CaCO}_{3}$ was rapidly pushed inside the reactor, followed by the setup of a filter at the outlet of the reactor. The filter was composed of a quartz tube, filled with $\mathrm{Ca}-\mathrm{HA}$ powder as reactive phase. Then, an air flow rate was applied in order to create a flue gas containing vaporized lead(II) through the Ca-HA filter. The analysis of $\mathrm{Pb}$ content introduced into the reactor before the reaction and remaining after the reaction allowed to determine the vaporized lead(II) fraction. This vaporized fraction may be condensed on the reactor wall, fixed on Ca-HA filter, or trapped in the final nitric acid solution. Elemental analyses of lead(II) present in the filter and in nitric acid solution allowed to deduce the gaseous lead(II) lost elsewhere in condensed form and complete the mass balance.

Figure 7 presents the reactivity of Ca-HA powder in the removal of lead(II) from a synthetic flue gas at different temperatures. When the temperature increased, the vaporized fraction of lead(II) increased. Since the Ca-HA filter was set at the outlet of the reactor, about one-third of vaporized lead(II) was condensed. In contact with Ca-HA filter, most vaporized lead(II) was fixed on the filter and only traces of lead(II) were found in $\mathrm{HNO}_{3}$ solution. This demonstrated that $\mathrm{Ca}-\mathrm{HA}$ powder also shows remarkable affinity for vaporized lead(II) in the gas phase. Further studies will be done in order to determinate the sorption capacity of Ca-HA and to understand the mechanism of lead fixation in gas phase.

\section{Synthesis of CAP and its bioactivity}

Under atmospheric pressure, $\mathrm{CO}_{2}$ formed from the decomposition of $\mathrm{CaCO}_{3}$ left automatically the reaction mixture. But a small amount of the initial carbonate was incorporated in the apatitic structure of the final Ca-HA particles, as shown by TG (Fig. 2, peak at $720^{\circ} \mathrm{C}$ ) to form CAP. There is great interest in the synthesis of this CAP, since it is well known to be more effective than Ca-HA for bone and dental tissue reconstitution [41, 42].

A modification of the present synthesis process was implemented in order to increase the carbonate content in $\mathrm{Ca}-\mathrm{HA}$ structure which needs to keep $\mathrm{CO}_{2}$ in contact with the reaction mixture. The objective was to obtain Ca-HA containing at least $4 \mathrm{wt} \%$ of carbonate in its molecular structure. This carbonate content is the classical value in 

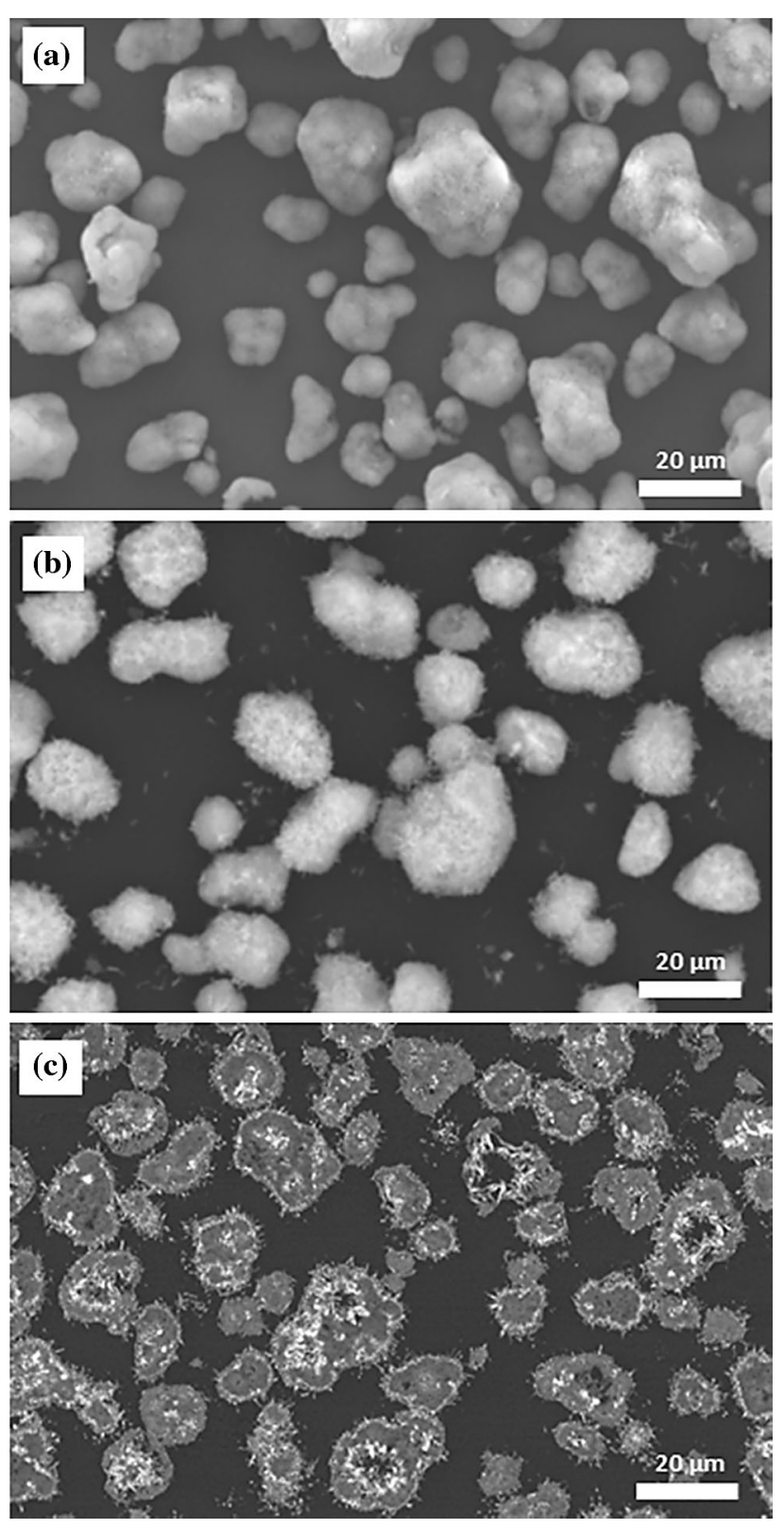

Fig. 5 SEM images of a Ca-HA powder dried at $105^{\circ} \mathrm{C}$, b lead(II)loaded Ca-HA powder, recovered after lead(II) removal, $\mathbf{c}$ lead(II)loaded Ca-HA powder after immobilization in a resin and polishing to look inside particles

the mineral fraction of human bone. For this synthesis, $10 \mathrm{~g} \mathrm{CaCO}_{3}$ and $45 \mathrm{~mL} \mathrm{H}_{2} \mathrm{O}$ were initially introduced in a $250 \mathrm{~mL}$ close stainless-steel reactor. After heating to $80{ }^{\circ} \mathrm{C}, 6.9 \mathrm{~g}$ of $\mathrm{H}_{3} \mathrm{PO}_{4}$ was quickly injected into the reactor by an injection valve and the reaction started by adjustment of the stirring rate at $800 \mathrm{rpm}$. The final pressure in the reactor was found to be about 13 bar, due to the formation of $\mathrm{CO}_{2}$ and the water vapor pressure at $80{ }^{\circ} \mathrm{C}$ in the closed reactor. After $48 \mathrm{~h}$ of reaction, the powder was recovered by filtration and drying steps. Details of the synthesis process were reported [32].

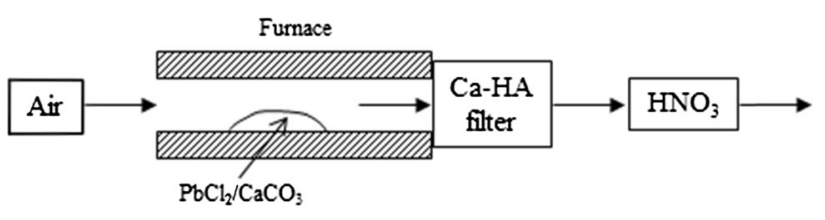

Fig. 6 Scheme of reactor for the fixation of lead(II) in gas phase on Ca-HA powder

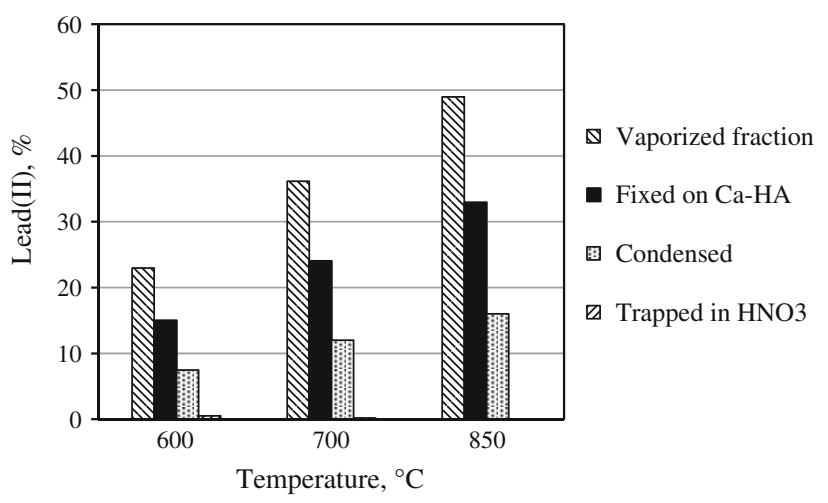

Fig. 7 Reactivity of Ca-HA powder in the removal of vaporized lead(II) at different temperatures

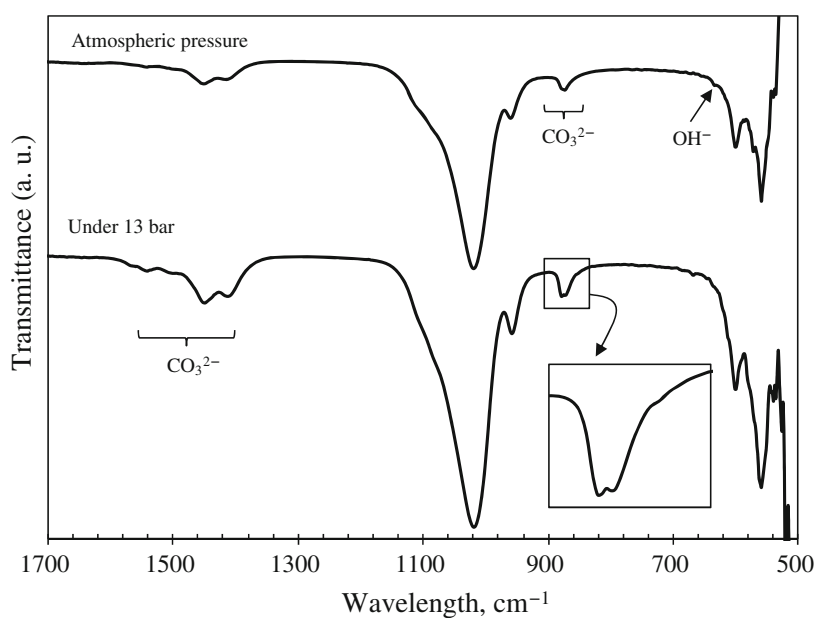

Fig. 8 IR spectra of Ca-HA powders synthesized under atmospheric pressure or under 13 bar from $\mathrm{CaCO}_{3}$ and $\mathrm{H}_{3} \mathrm{PO}_{4}$

Figure 8 compares IR spectra of two solids obtained under atmospheric pressure and under 13 bar. Peaks of phosphate groups were found at 1310-900 and $620-500 \mathrm{~cm}^{-1}$. The low-intensity peak at $630 \mathrm{~cm}^{-1}$ was attributed to hydroxyl groups. As expected, characteristic peaks of carbonate groups inserted in the apatitic structure were found at $1545,1450,1415,880$, and $870 \mathrm{~cm}^{-1}$ [32]. The intensity of the carbonate bands of the product synthesized at 13 bar was much higher than that of the product 


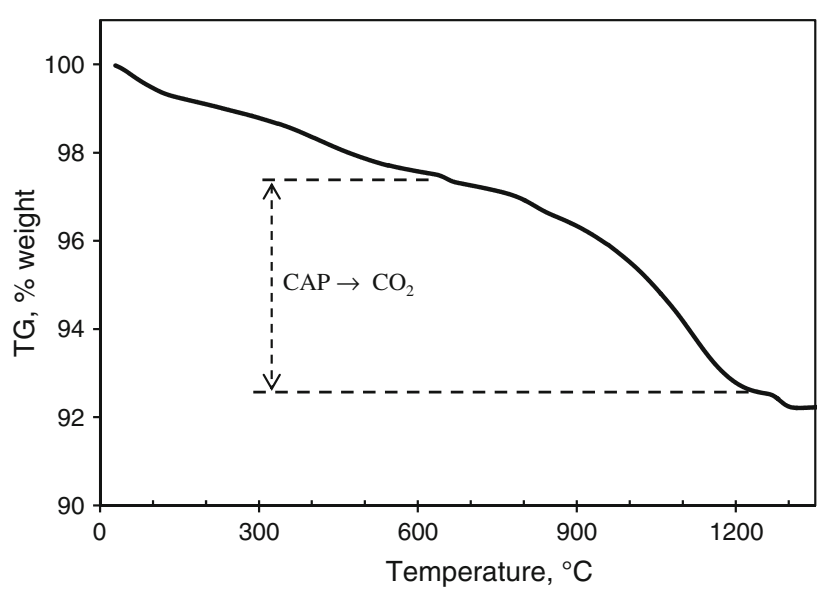

Fig. 9 TG analysis of the product synthesized at $80{ }^{\circ} \mathrm{C}$ under 13 bar $\mathrm{CO}_{2}$ pressure; the decarbonation of CAP in the temperature range of $740-1250{ }^{\circ} \mathrm{C}$ was confirmed by mass spectroscopy analysis of the gas from the outlet of TG analyzer, as shown elsewhere [27]
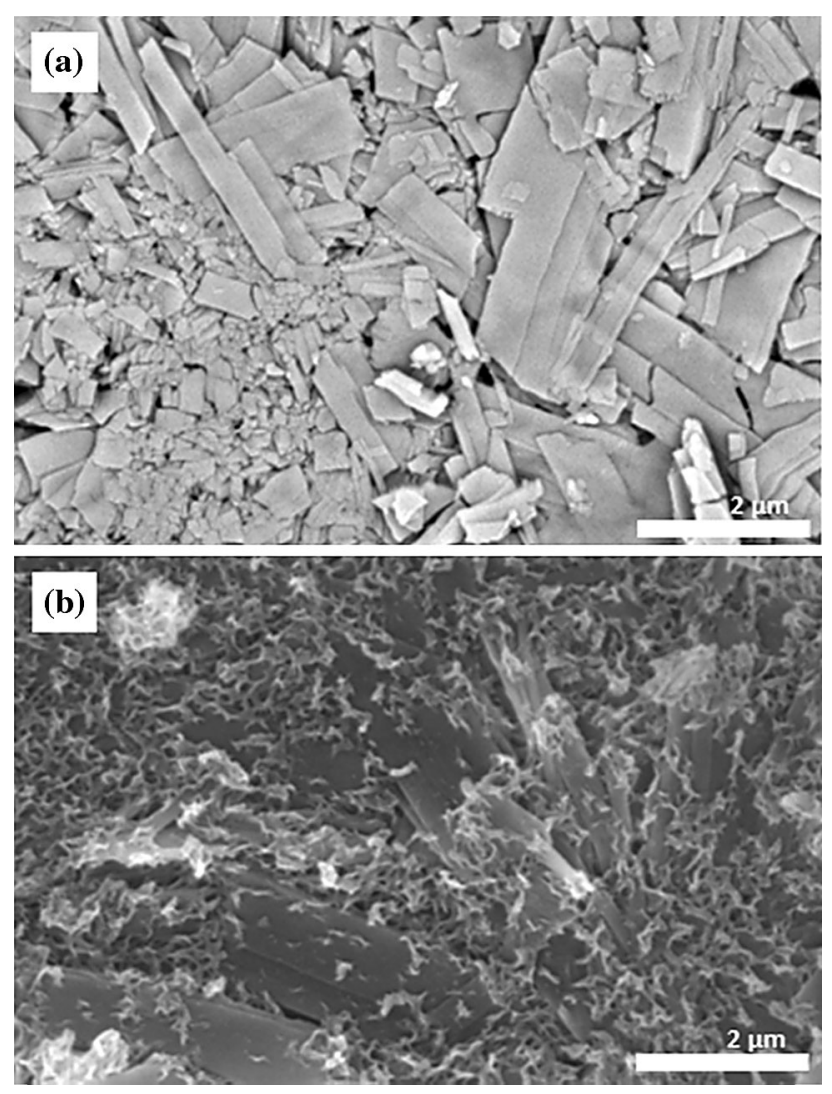

Fig. 10 SEM images of Ca-HA synthesized at $80{ }^{\circ} \mathrm{C}$ under $\mathrm{CO}_{2}$ pressure before (a) and after (b) incubation in Tris-SBF-27 mM

synthesized at atmospheric pressure. To quantify this difference, TG analysis was performed on the product synthesized at 13 bar and the result is presented in Fig. 9. Only a trace amount of remaining unreacted $\mathrm{CaCO}_{3}$, which was decomposed at about $610{ }^{\circ} \mathrm{C}$, was observed and was confirmed by XRD characterization. From the decarbonation of CAP in the temperature range of $740-1250{ }^{\circ} \mathrm{C}$, the carbonate content of the product was determined to reach $4.8 \mathrm{wt} \%$. This was higher than the carbonate content of the product synthesized at $80{ }^{\circ} \mathrm{C}$ under atmospheric pressure for $24 \mathrm{~h}$ of reaction (Fig. 2), which was only $2.5 \%$. So, the contact of the reaction mixture with pressurized $\mathrm{CO}_{2}$ atmosphere increased the carbonate content in $\mathrm{Ca}-\mathrm{HA}$ structure as could be expected.

The bioactivity test was then carried out for CAP synthesized under high- $\mathrm{CO}_{2}$ pressure. Details of this test were described elsewhere [32]. As shown in Fig. 10, after incubation in Tris-SBF-27 mM, the surface of CAP was covered by new calcium phosphate deposits resembling those described in earlier observations [43]. This coating related to good bioactivity of synthesized CAP, appropriate for bone and dental tissue reconstitution.

\section{Conclusions}

Ca-HA was successfully synthesized from $\mathrm{CaCO}_{3}$ and $\mathrm{H}_{3} \mathrm{PO}_{4}$ as convenient and low-cost starting materials by a one-step synthesis process operated at moderate reaction conditions $\left(80^{\circ} \mathrm{C}, 24 \mathrm{~h}\right.$, and atmospheric pressure). $\mathrm{CaCO}_{3}$ powder reactant could be completely decomposed and both initial products could be totally precipitated into Ca-HA. This synthesis process demonstrated several advantages compared to other methods starting from soluble calcium salts. Ca-HA could be obtained in gel or powder forms which were found to be active in the bioactivity test, and to be very efficient in the fixation of lead as a toxic model metal in liquid or gas phases. This opens new approaches in enlarging the use of $\mathrm{Ca}-\mathrm{HA}$ for environmental purposes and for biomaterial development, when $\mathrm{Ca}-\mathrm{HA}$ can be easily obtained from economical starting materials using simple one-step synthesis process.

Acknowledgements The authors thank gratefully colleagues at RAPSODEE Center, Christine Rolland, Céline Boachon, Bernard Auduc, Denis Marty, for their technical help.

\section{References}

1. Pham Minh D, Lyczko N, Sebei H, Nzihou A, Sharrock P (2012) Synthesis of calcium hydroxyapatite from calcium carbonate and different orthophosphate sources: a comparative study. Mater Sci Eng B 177:1080-1089

2. Morgan H, Wilson RM, Elliott JC, Dowker SEP, Anderson $P$ (2000) Preparation and characterisation of monoclinic hydroxyapatite and its precipitated carbonate apatite intermediate. Biomaterials 21:617-627 
3. Murakami S, Kato K, Enari Y, Kamitakahara M, Watanabe N, Ioku K (2012) Hydrothermal synthesis of porous hydroxyapatite ceramics composed of rod-shaped particles and evaluation of their fracture behavior. Ceram Int 38:1649-1654

4. http://www.innophos.com/en/products-and-markets/browse-productcategories/phosphate-salt/tricalcium-phosphates/calipharm-t. Accessed Feb 2013

5. Rodriguez-Lorenzo LM, Vallet-Regi M, Ferreira JMF (2001) Fabrication of hydroxyapatite bodies by uniaxial pressing from a precipitated powder. Biomaterials 22:583-588

6. Matsumura Y, Moffat JB (1993) Catalytic oxidative coupling of methane over hydroxyapatite modified with lead. Catal Let 17:197-204

7. Tsuchida T, Kubo J, Yoshioka T, Sakuma S, Takeguchi T, Ueda W (2008) Reaction of ethanol over hydroxyapatite affected by $\mathrm{Ca} / \mathrm{P}$ ratio of catalyst. J Catal 259:183-189

8. Verwilghen C, Rio S, Nzihou A, Gauthier D, Flamant G, Sharrock PJ (2007) Preparation of high specific surface area hydroxyapatite for environmental applications. J Mater Sci 42:6062-6066. doi:10.1007/s10853-006-1160-y

9. Venugopal A, Scurrell MS (2003) Hydroxyapatite as a novel support for gold and ruthenium catalysts behaviour in the water gas shift reaction. Appl Catal A Gen 245:137-147

10. Kanai H, Nakao M, Imamura S (2003) Selective photoepoxidation of propylene over hydroxyapatite-silica composites. Catal Com 4:405-409

11. Baillez S, Nzihou A, Bernache-Assolant D, Champion E, Sharrock P (2007) Removal of aqueous lead ions by hydroxyapatites: equilibria and kinetic processes. J Hazard Mater 139:443-446

12. Fernane F, Mecherri MO, Sharrock P, Hadioui M, Lounici H, Fedoroff M (2008) Sorption of cadmium and copper ions on natural and synthetic hydroxylapatite particles. Mater Charact 59:554-559

13. Nzihou A, Sharrock P (2010) Role of phosphate in the remediation and reuse of heavy metal polluted wastes and sites. Waste Biomass Valor 1:163-174

14. Fernane F, Mecherri MO, Sharrock P, Fiallo M, Sipos R (2010) Mater Sci Eng C 30:1060-1064

15. Pham Minh D, Sebei H, Nzihou A, Sharrock P (2012) Apatitic calcium phosphates: synthesis, characterization and reactivity in the removal of lead(II) from aqueous solution. Chem Eng J 198-199:180-190

16. Sharrock P, Brumas V, Fiallo MML (2013) Wastewater sorption on HA: old recipes for new tastes. Proc Earth Planet Sci 7:256-259

17. Oliva J, De Pablo J, Cortina J-L, Cama J, Ayora C (2011) Removal of cadmium, copper, nickel, cobalt and mercury from water by Apatite IITM: column experiments. J Hazard Mater 194:312-323

18. Jarcho M, Bolen CH (1976) Hydroxylapatite synthesis and characterization in dense polycrystalline form. J Mater Sci 11:2027-2035. doi:10.1007/BF02403350

19. Hayek E, Newesely H (1965) Pentacalcium monohydroxyorthophosphate (Hydroxylapatite). Inorg Synth 7:63-65

20. Eanes ED, Gillessen IH, Posner AS (1965) Intermediate states in the precipitation of hydroxyapatite. Nature 208:365-367

21. Bezzi G, Celotti G, Landi E, La Torretta TMG, Sopyan I, Tampieri A (2003) A novel sol-gel technique for hydroxyapatite preparation. Mater Chem Phys 78:816-824

22. Anee TK, Ashok M, Palanichamy M, Narayana Kalkura S (2003) A novel technique to synthesize hydroxyapatite at low temperature. Mater Chem Phys 80:725-730

23. Tredwin CJ, Young AN, Georgiou G, Shin S-H, Kim H-W, Knowles J-C (2013) Hydroxyapatite, fluor-hydroxyapatite and fluorapatite produced via the sol-gel method. Optimisation, characterisation and rheology. Dental Mater 29:166-173

24. Bakan F, Laçin O, Sarac H (2013) A novel low temperature solgel synthesis process for thermally stable nano crystalline hydroxyapatite. Powder Technol 233:295-302
25. Saha SK, Banerjee A, Banerjee S, Bose S (2009) Synthesis of nanocrystalline hydroxyapatite using surfactant template systems: role of templates in controlling morphology. Mater Sci Eng C 29:2294-2301

26. Gopi D, Indira J, Kavitha L, Sekara M, Mudali UK (2012) Synthesis of hydroxyapatite nanoparticles by a novel ultrasonic assisted with mixed hollow sphere template method. Spectrochim Acta A 93:131-134

27. Silva CC, Pinheiro AG, Miranda MAR, Góes JC, Sombra ASB (2003) Structural properties of hydroxyapatite obtained by mechanosynthesis. Solid State Sci 5:553-558

28. Nasiri-Tabrizi B, Fahami A, Ebrahimi-Kahrizsangi R (2014) A comparative study of hydroxyapatite nanostructures produced under different milling conditions and thermal treatment of bovine bone. J Ind Eng Chem 20:245-258

29. Conn JF, Jessen LA (1980) Process for producing hydroxyapatite. US Patent 4,324,772

30. Lazic S, Zec S, Miljevic N, Milonjic S (2001) The effect of temperature on the properties of hydroxyapatite precipitated from calcium hydroxide and phosphoric acid. Thermochim Acta 374:13-22

31. Elliott JC (1994) Studies in inorganic chemistry 18: structure and chemistry of the apatites and other calcium orthophosphates. Elsevier, Amsterdam

32. Pham Minh D, Tran ND, Nzihou A, Sharrock P (2013) Carbonate-containing apatite (CAP) synthesis under moderate conditions starting from calcium carbonate and orthophosphoric acid. Mater Sci Eng C 33:2971-2980

33. Liao CJ, Lin FH, Chen KS, Sun JS (1999) Thermal decomposition and reconstitution of hydroxyapatite in air atmosphere. Biomaterials 20:1807-1813

34. Parhi P, Ramanan A, Ray AR (2004) A convenient route for the synthesis of hydroxyapatite through a novel microwave-mediated metathesis reaction. Mater Lett 58:3610-3612

35. Lim GK, Wang J, Ng SC, Gan LM (1999) Formation of nanocrystalline hydroxyapatite in nonionic surfactant emulsions. Langmuir 15:7472-7477

36. Jillavenkatesa A, Condrate RA (1998) Sol-gel processing of hydroxyapatite. J Mater Sci 33:4111-4119. doi:10.1023/A: 1004436732282

37. Rey C, Combes C, Drouet C, Lebugle A, Sfihi H, Barroug A (2007) Nanocrystalline apatites in biological systems: characterisation, structure and properties. Mater Sci Eng Technol 38:996-1002

38. Banu M (2005) Mise en forme d'apatites nanocristallines : céramiques et ciments. $\mathrm{PhD}$ dissertation, Institut National Polytechnique de Toulouse, France

39. Miyake M, Watanabe K, Nagayama Y, Nagasawa H, Suzuki T (1990) Synthetic carbonate apatites as inorganic cation exchangers: exchange characteristics for toxic ions. J Chem Soc Faraday Trans 86:2303-2306

40. Rio S, Verwilghen C, Ramaroson J, Nzihou A, Sharrock P (2007) Heavy metal vaporization and abatement during thermal treatment of modified wastes. J Hazard Mater 148:521-528

41. Rodrigues CVM, Serricella P, Linhares ABR, Guerdes RM, Borojevic R, Rossi MA, Duarte MEL, Farina M (2003) Characterization of a bovine collagen-hydroxyapatite composite scaffold for bone tissue engineering. Biomaterials 24:4987-4997

42. Thian ES, Ahmad Z, Huang J, Edirisinghe MJ, Jayasinghe SN, Ireland DC, Brooks RA, Rushton N, Bonfield W, Best SM (2008) The role of electrosprayed apatite nanocrystals in guiding osteoblast behavior. Biomaterials 29:1833-1843

43. Jalota S, Bhaduri SB, Tas AC (2008) Using a synthetic body fluid (SBF) solution of $27 \mathrm{mM} \mathrm{HCO}_{3}{ }^{-}$to make bone substitutes more osteointegrative. Mater Sci Eng C 28:129-140 